\title{
DEVELOPMENT AND VALIDATION ZIC HILIC COULOMN FOR SIMULTANEOUS DETERMINATION OF FUROSEMIDE AND INDAPAMIDE AS DOPING
}

\author{
Iswandi $^{1}$, Daryono H. Tjahjono ${ }^{2}$, Slamet Ibrahim ${ }^{3}$ \\ ${ }^{1}$ Pharmacy of School, ITB \\ ${ }^{2}$ Pharmacy of School, ITB \\ ${ }^{3}$ Pharmacy of School, ITB
}

\begin{abstract}
In sports, doping abuse done by athletes has been done since the 18th century. Many of the drugs used for doping and its chemical properties vary. Based on a list issued by the World Anti Doping Agency, one of the doping categories is diuretic. Then the most appropriate testing method is needed to seperation furosemide and indapamide. This study aims to see the development and validation of the separation furosemide and indapamide as doping compounds with High Performance Liquid using the Zic - HILIC column.

This study used High Performance Liquid Chromatography of Shidmazu LC 20 AD brand with iso-fed pump and SPD 20A UV-Vis detector. The column used is Zic - HILIC $(150 \times 4.6 \mathrm{~mm} ; 5 \mu \mathrm{m})$. This research is carried out on the optimization of conditions including mobile phase velocity, mobile phase $\mathrm{pH}$, buffer of mobile phase, and buffer concentration. Selection of selected conditions see the price of $\mathrm{R}>1.5$ and $\mathrm{N}>>>$ or HETP $<<<$ Optimized wavelength results $276 \mathrm{~nm}$. The separation conditions of the furosemide and indapamide mixtures by HPLC using Zic-HILIC columns (150 x $4.6 \mathrm{~mm}, 5 \mu \mathrm{m})$ are Acetonitrile: Ammonium Acetate buffer ( $5 \mathrm{mM}, \mathrm{pH} \mathrm{5}$ ) (95: 5) with a velocity of $0.5 \mathrm{ml} /$ minute. The selected condition gives the given resolution value $>1.5$ and the $\mathrm{N}$ price is the greatest. The method was than validated forSelectivity, linearity,accuracy, precision, limits ofdetection and limits ofquantification. The calibration curve of furosemide and indapamide were linear with a regression coefficient $R>0.999$.
\end{abstract}

\section{Keyword : Zic Hilic Coulomn, Furosemide, Indapamide}

\section{Introduction}

Sports is a place where there is a process of interaction between humans and contains ethical values that are shown, tested and learned from each other. The value involved in sports does not only include body or intellectual involvement but also humanity as a whole, such as fair play, teamwork, and sportsmanship. Since 1967, have been deaths among cyclists, soccer players and boxers due to the use of "wake amine" or "vasodilatator" and contestants who died of heroin poisoning. There is no sport that is free from doping to this day. (Müller R.T, 2010) Based on the list issued by the World Anti-Doping Agency, there are 9 doping categories, one of which category is a diuretic. (Anonim, 2014)

Then the most suitable testing method is needed to analyze diuretic drugs. The analytical method that is often used in doping analysis is gas chromatography, liquid chromatography, and electrophoresis. The problem is analyzing the drug for hydrophilic compounds (Park, J., et al., 1989; Hatton, C. K, 2007: Kolmonen .M, 2011). Furosemide and Indampide are a class of diuretic drugs that can be used as doping. But Furosemide and Indapmide including hydrophilic drug 
compounds are difficult to separate and analyze.

Until now, widely known separation models at HPLC include normal (NP), reverse phase (RP), ion exchange, exclusive size, chiral separation and affinity models. But for the separation of polar compounds it becomes a problem (Ikegami et al, 2006). One solution to the problem for hydrophilic compounds has been done using the HILIC column (Ikegami et al, 2006).

\section{Methods}

Apparatus<smiles>NS(=O)(=O)c1cc(C(=O)O)c(NCc2ccco2)cc1Cl</smiles>

HPLC Type Agilent 1100 Series Low Presre Gradient, Column: ZIC - HILIC 100 $\mathrm{mm} \times 2.1 \mathrm{~mm}$ x $5 \mu \mathrm{m}$, Photo Diode Array (PDA) detector, Hewlett Packard V - Vis Spectrophotometer HP) 8452 A, Analytical balance Mettler Toledo 37600, , Socorex Calibra 822 made Switzerland, nylon membrane filter $0.2 \mu \mathrm{m}, 13 \mathrm{~mm}$ Whatmann and filters $0.2 \mu \mathrm{m}, 47 \mathrm{~mm}$ and glassware

\section{Reagent}

Furosemide (Sigma), Indapamide (Sigma), Ammonium Acetate (Merck), Sodium Acetate (Merck), Acetonitrile for HPLC, Methanol for HPLC, Aqua for HPLC<smiles>CC1Cc2ccccc2N1NC(=O)c1ccc(Cl)c(S(N)(=O)=O)c1</smiles>

Figure 1. The structure of Furosemide (a) and Indapamide (b)

\section{Sample Preparation}

Thoroughly weighed standard Furosemide and Indapamide with concentration $1.0 \mathrm{mg} / \mathrm{ml}$ in Acetonitrile: Water (90: 10)

\section{Optimum wavelength}

The standard solution was prepared from standard solution of Furosemide and Indapmide each $100 \mathrm{ppm}$, filtered by Whatman membrane filter of $0.2 \mu \mathrm{m}$ pore diameter and then injected to the HPLC as much as $20 \mu \mathrm{l}$. Spectra is seen using Diode
Array detector at HPLC. Observation of spectra at wavelength $200-400 \mathrm{~nm}$.

Optimization HPLC

Optimization of HPLC conditions with some effect of the condition in the analysis. Conditions made include: mobile phase composition, speed of mobile phase, buffer concentration, buffer type, organic solvent and $\mathrm{pH}$. The standard mixed solution was injected as much as $20 \mu \mathrm{l}$ using a composition which was varied based on the effect of the condition in the analysis.

\section{Result and Discussion}

\section{Effect of concentration phase concentration variation}

Table 1. Effect of concentration phase concentration variation

\begin{tabular}{|c|c|c|c|}
\hline $\begin{array}{c}\text { Acetonitril : Dapar Amonium } \\
\text { Asetat }\end{array}$ & Compound & $\mathrm{N}$ & $\mathrm{R}$ \\
\hline \multirow{2}{*}{$95: 5$} & Furosemide & 3983.422 & \multirow{2}{*}{2.64} \\
\hline & Indapamide & 7440.957 & \\
\hline \multirow{2}{*}{$90: 10$} & Furosemide & 1029.453 & \multirow{2}{*}{1.43} \\
\hline & Indapamide & 2461.573 & \\
\hline \multirow{2}{*}{$85: 15$} & Furosemide & 913.105 & \multirow{2}{*}{0.54} \\
\hline & Indapamide & 4106.128 & \\
\hline
\end{tabular}


The mobile phase composition of Acetonitrile: Ammonium Acetate buffer with a selected between (95: 5), (90:10) and (85:
15) is (95: 5) . The given resolution is 2.64 (>

1.5) and the largest N.

\section{Effect of $\mathrm{pH}$ variation of buffer}

Table 2. Effect of $\mathrm{pH}$ Ammonium Acetate

\begin{tabular}{|c|c|c|c|}
\hline \multirow{2}{*}{$\mathrm{pH}$ Amonium Acetate } & Compound & $\mathrm{N}$ & $\mathrm{R}$ \\
\hline \multirow{2}{*}{4,0} & Furosemide & - & \multirow{2}{*}{-} \\
\cline { 2 - 3 } & Indapamide & - & \\
\hline \multirow{2}{*}{5,0} & Furosemide & 3983.22 & \multirow{2}{*}{2.64} \\
\cline { 2 - 3 } & Indapamide & 7440.957 & \\
\hline \multirow{2}{*}{6,0} & Furosemide & $3107, .00$ & 1.76 \\
\hline
\end{tabular}

The $\mathrm{pH}$ variation of the ammonium acetate buffer in the mobile phase comparison selected between $\mathrm{pH} 4, \mathrm{pH} 5$ and $\mathrm{pH} 6$ is $\mathrm{pH}$, this is because the resulting resolution is $2.64(>1,5)$ and the largest $\mathrm{N}$.

\section{Effect of buffer concentration}

Table 3. Effect of Ammonium Acetate Concentration

\begin{tabular}{|c|l|c|c|}
\hline \multirow{2}{*}{$\mathrm{pH}$ Ammonium Acetate } & Compound & $\mathrm{N}$ & $\mathrm{R}$ \\
\hline \multirow{2}{*}{$5,0 \mathrm{mM}$} & Furosemide & 3983.422 & \multirow{2}{*}{2.64} \\
\cline { 2 - 3 } & Indapamide & 7440.957 & \multirow{2}{*}{2.27} \\
\hline \multirow{2}{*}{$10,0 \mathrm{mM}$} & Furosemide & 2503.363 & \multirow{2}{*}{1.84} \\
\cline { 2 - 3 } & Indapamide & 5323.411 & 1898.422 \\
\cline { 2 - 3 } & Furosemide & 4044.957 & \multirow{2}{*}{$20,0 \mathrm{mM}$} \\
\cline { 2 - 3 } & Indapamide & \\
\hline
\end{tabular}

Variations of concentration of Ammonium Acetate buffer ( $\mathrm{pH}$ 5) selected between 5 $\mathrm{mM}, 10 \mathrm{mM}$ and $20 \mathrm{mM}$ were $5 \mathrm{mM}$. The resulting resolution is 2.64 and the value $\mathrm{N}$ is the greatest.

\section{Effect of flow rate}

Table 4. Effect of flow rate

\begin{tabular}{|c|c|c|c|}
\hline Flow rate & Compound & $\mathrm{N}$ & $\mathrm{R}$ \\
\hline \multirow{2}{*}{$1,0 \mathrm{ml} /$ minute } & Furosemide & 1848.230 & \multirow{2}{*}{1.24} \\
\cline { 2 - 3 } & Indapamide & 4182.315 & \\
\hline \multirow{2}{*}{$0,75 \mathrm{ml} /$ minute } & Furosemide & 2427.516 & \multirow{2}{*}{1.45} \\
\cline { 2 - 3 } & Indapamide & 3915.660 & \\
\hline $0,5 \mathrm{ml} /$ minute & Furosemide & 3234.213 & 1.99 \\
\hline
\end{tabular}

Variations in flow rate velocity between $1 \mathrm{ml}$ / $\min .0 .75 \mathrm{ml} / \mathrm{min}$ and $0.5 \mathrm{ml} / \mathrm{min}$ selected is $0.5 \mathrm{ml} / \mathrm{min}$. The given resolution is $>1.5$ and the $\mathrm{N}$ price is the greatest of the three speeds varied. 


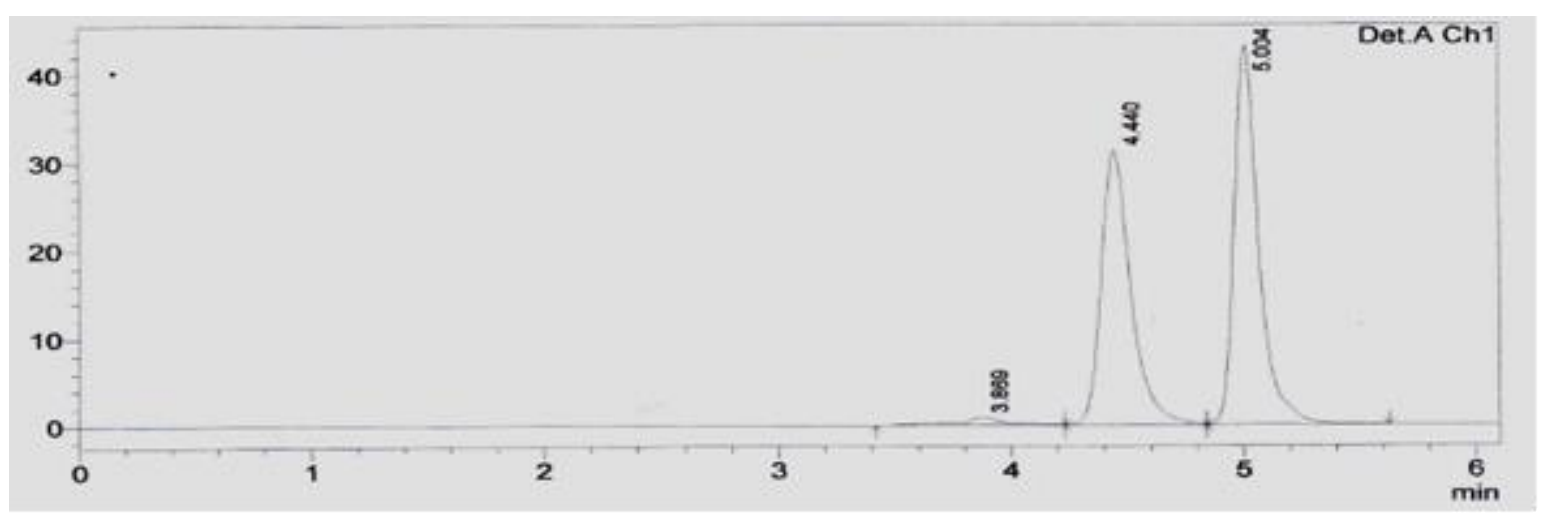

Figure 2. Effect of Ammonium Acetate Concentration Variation

\section{Methode Validation}

After the found of conditions were optimized separated Furosemide and
Indapmide, The method was validated as ICH guidelines such as linearity, accuracy, precision, LOD and LOQ

\section{Liniearitas}
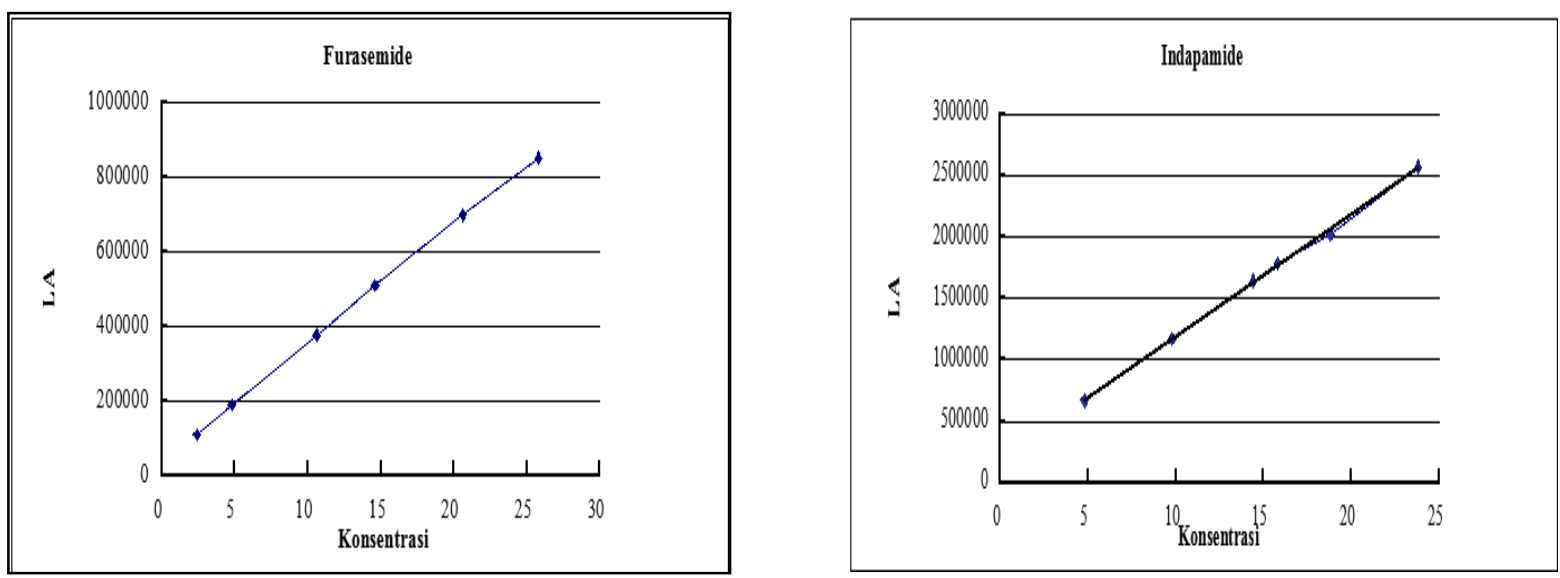

Figure 3. Linearity of Furosemid and Indapamide

Table 5. Liniear Regersiaon data of Furosemid and Indapamide

\begin{tabular}{|l|c|c|}
\hline Validation Parameter & Furosemide & Indampide \\
\hline Liniearitry Range & $2,0-25$ & $5-25$ \\
\hline Correlation coefficient & 0.9997 & 0.9988 \\
\hline LOD & 0,6025 & 0,8694 \\
\hline LOQ & 1,8258 & 2,6346 \\
\hline
\end{tabular}

Corelation coefficientfor Furosemide and Indapamide should be equal or greater than 0.999 (R calc. > R table; Vxo eligiliblity no more than $5 \%$ ) 



\begin{tabular}{|c|c|c|c|c|}
\hline \multirow{2}{*}{ Furosemide } & \multicolumn{3}{|c|}{ Acuracy } & Precision \\
\cline { 2 - 5 } & $\mathbf{8 0} \%$ & $\mathbf{1 0 0 \%}$ & $\mathbf{1 2 0} \%$ & $1.99 \%$ \\
\hline Indampide & $100.07 \% \pm 0.63$ & $99.68 \% \pm 0.20$ & $99.73 \% \pm 0.65$ & $1.84 \%$ \\
\hline
\end{tabular}

Accuracy and precisionFfurosemide and Indmapaide accepted to requirement (acceptance criteria $80-110 \%$ for Accuray and precision CV is less than $2 \%$ )

\section{Conclusion}

The separation conditions of the Furosemide and Indapamide mixtures by HPLC using Zic-HILIC columns (150 x 4.6 mm, $5 \mu \mathrm{m})$ are Acetonitrile: Ammonium Acetate buffer (5 $\mathrm{mM}, \mathrm{pH}$ 5) (90: 10) with a velocity of $0.5 \mathrm{ml} /$ minute.

\section{Reference}

Alpert AJ., 2008,Electrostatic repulsion hydrophilic interaction chromatography for isocratic separation of charged solutes and selective isolation of phosphopeptides. Journal Analytical Chemistry volume 80, 62 $-76$

Boersema P.J., and Shabaz M., 2008, Hidrophilic Interaction Liquid Chromatography (HILIC) in Proteomics, Anal. Bioanl Chem, 391. $151-159$

Carr, G.P dan Wahlich J.C, 1990, Practical Approach to Method Validation in Pharmaceutical Analysis. Journal of Pharmaceutical and Biomedical Analysis, Volume 8.612-618.

De Boer, D., Höld, K., Crouch, D., Wilkins, D., Rolling, D. and Maes, R. ,1999, The potential use of hair in doping control in general and in the detection of stanozololin particular, in W.Schänzer, H.Geyer, A.GotzmannandU. Mareck- Engelke(eds), Recent Advances in Doping Analysis, Vol.7of 15th Cologne Workshop on Dope Analysis, Sport verlag Strauß,pp.41-47.

Gaillard, Y., Vayssette,F. And Pépin,G., 2000, Compared interest between hair analysis and urin analysis in doping controls. Results for amphetamines, corticosteroids and anabolic steroids in racing cyclists, Forensic Sci Int 107: 316-379.
Hatton, C.K, 2007, Beyond Sport-Doping Headlines : The Science of Laboratory Tests for Performance-Enhancing Drug. Anti-Doping Research, Elsevier 1 -25.

Hemstroem P and Irgum K, 2006, Hydrophilic interaction chromatography. Journal of Separation Science Volume 29, 1784 1821.

Ikegami T., Fujita H., and Horie K., 2006, HILIC Mode Separation of Polar Compounds by Monolithic Silica Capillary Columns Coated with Polyacrlamide, Anal. Bioanl Chem, 386.

Kintz, P. dan Samyn, N. , 2002, Use of alternative specimens : Drugs of abuse in saliva and doping agents in hair, Ther Drug Monit 24: 239-246.

Kolmonen,M.,Leinonen, A.,Kuuranne,T.,Pelander,A.andOjanperä,I.( 2010). Quantitation of morphine and its glucuronides in human urine by HILIC TOFMS, in W.Schänzer,H.Geyer,A.GotzmannandU.

Mareck(eds), RecentAd- vancesin DopingAnalysis, Vol.18 of 28th Cologne Workshop on Dope Analysis, Sport verlag Strauß, pp.9-16.

Müller R.K., 2010, History of Doping and Doping Control, in Thieme D and Hemmersbach P (eds), Doping in Sport, Springer - Verlag Berlin Heidelberg, 1- 23

Naidong W,2003 : Bioanalytical liquid chromatography tandem mass spectrometry methods on underivatized silica columns with aqueous/organic mobile phases, Journal of Chromatography A, Volume 796. $209-224$

Park ,J., Song-Ja, P., Dong S.L., Haeyoung P.C., Bongchull, C., Changno Y., Hongki M., Myung J.C., 1989, Review of the Seoul Laboratory Activities - Seoul Olympic Games 1988, Official Proceedings, IInd I.A.F World Symposium on Doping Sport 
International Atheletic Foundation, Montecarlo, $47-61$

Peters,R., Stolker,A., Mol,J., Lommen,A., Lyris,E., Angelis,Y., Vonaparti, A., Stamou,M., Georgakopoulos,C. And Nielen,M. , 2010. Screening in veterinary drug analysis and sports doping control based full-scan, accurate mass spectrometry, Trendsin Anal Chem 29 (11): 1250-1268.

Rivier,L., 2000, Is therea place for hair analysis in doping controls?, Forensic Sci Int 107: 309-323.

Skoog, D.A., Holler F.J and Nieman, T.A., 1998, Principles of Instrumanetal Analysis. Fifth Edition, USA ;Thomson Learnng Inc. $674-696$

Trout,G.J.and Kazlauskas,R., 2004,. Sports drug testing-ananalyst' sperspective, Chem Socrev 33: 1-13.

Watson, D.G 2000, Pharmaceutical Analysis : A Textbook for Pharmacy Student and Pharmaceutical Chemists, London, Churchill Livingstone.

Yuyan W, 2009 Development and evaluation of new silica based polar and / or mixed modal stationary phases for HPLC ; Disertation, Universiteit Wien. 1 - 22 
